Brit. J. industr. Med., 1960, 17, 260.

\title{
DIFFUSE PLEURAL MESOTHELIOMA AND ASBESTOS EXPOSURE IN THE NORTH WESTERN CAPE PROVINCE
}

\author{
BY \\ J. C. WAGNER, C. A. SLEGGS, and PAUL MARCHAND \\ From the Pathology Division, Pneumoconiosis Research Unit of the Council for Scientific and \\ Industrial Research, Johannesburg, West End Hospital, Kimberley, and the \\ Department of Thoracic Surgery, University of the Witwatersrand and Johannesburg General Hospital
}

(RECEIVED FOR PUBLICATION APRIL 24, 1960)

Primary malignant tumours of the pleura are uncommon. Thirty-three cases $(22$ males, 11 females, ages 31 to 68) of diffuse pleural mesothelioma are described; all but one have a probable exposure to crocidolite asbestos (Cape blue). In a majority this exposure was in the Asbestos Hills which lie to the west of Kimberley in the north west of Cape Province. The tumour is rarely seen elsewhere in South Africa.

Mesothelioma of the pleura is regarded as an uncommon tumour. In the last four years we have seen 33 histologically proven cases; 28 of these had some association with the Cape asbestos field and four cases had been exposed to asbestos in industry.

The tumour is rarely encountered elsewhere in South Africa. During the past five years, with the exception of the present series, no neoplasm of this nature has been diagnosed amongst 10,000 lungs examined at the Pneumoconiosis Bureau in Johannesburg, or in the Pathology Department of the South African Institute for Medical Research. Higginson and Oettle (1957) did not observe a single case in their survey of malignant tumours occurring in the Bantu and Cape Coloured population of Johannesburg and the North Eastern Transvaal.

Our first necropsy specimen of pleural mesothelioma with asbestosis was examined at the Pneumoconiosis Research Unit in February, 1956 (Case 1). During the early months of that year, one of us (C.A.S.) in the Northern Cape, treated six patients with gross pleural thickening. Pleural biopsies from two of them showed the features of mesothelioma. In the ensuing two years, eight further cases were found from this region and five from elsewhere in the Union. During this period C.A.S. had become perturbed at the number of these unusual tumours occurring amongst his patients, and stimulated an investigation. At this stage there were two reasons to suggest that asbestos might be implicated. First, asbestos was found in the lungs of the first case (Case 1), and secondly, 10 of the cases came from a hospital to which suspected cases of tuberculosis were referred from a large asbestos mining area. This hypothesis could not be supported at once from the original histories obtained from the patients, for they included housewives, domestic servants, cattle herders, farmers, a water bailiff, an insurance agent, and an accountant, none of whom were working on the asbestos mines at the time. We therefore undertook a detailed investigation of their past occupation and place of residence, and the association with asbestos exposure was discovered. The cases are summarized in Table 3. Previous biopsy specimens were reexamined, and new cases diagnosed, including asbestos miners. In only one case do the relatives deny that the patient either visited the asbestos mines or was exposed to asbestos.

This is a preliminary publication and the problem is being intensively investigated.

\section{The Asbestos Area of the North-West Cape}

According to Hall (1930) asbestos was discovered by Lichenstein near Prieska during his travels between 1803 and 1806. Since then it has been established that the asbestos deposits extend from 20 miles south of Prieska, northwards through the western part of the magisterial district of Hay, to the eastern portion of the magisterial district of Postmasburg and finally, to the western area of the 


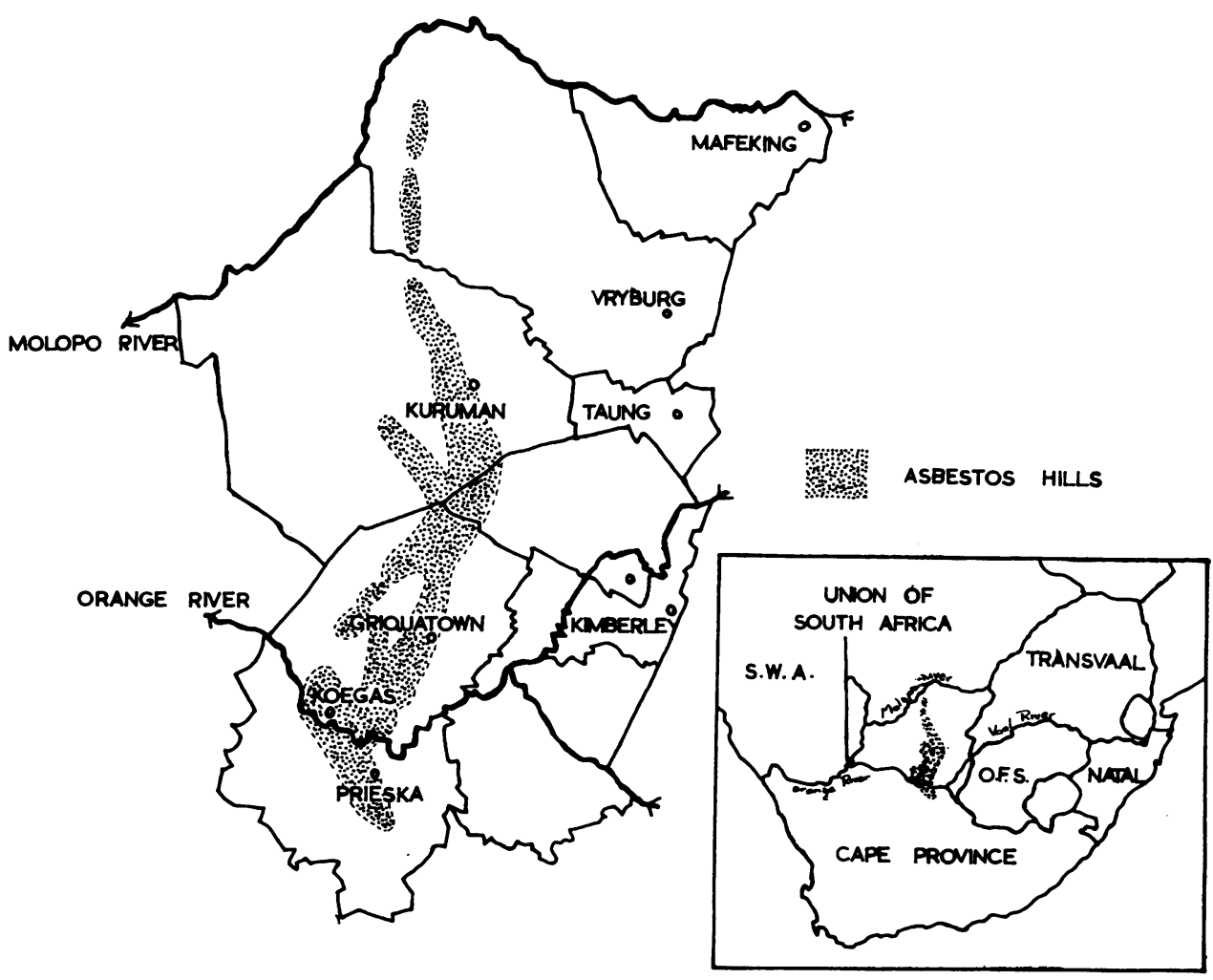

Fig. 1.-Map of Griqualand West asbestos fields.

district of Kuruman (Fig. 1). These deposits occur in the slopes of a range of hills covering an area of approximately 8,000 square miles. Known as the "Asbestos Mountains", these hills extend more or less longitudinally between $22.30^{\circ}$ and $23^{\circ} \mathrm{E}$. The whole area is semi-arid, sparsely populated, and, apart from mining, cattle ranching is the only important occupation. In the Kuruman area several large tracts of land in or abutting on these mountains have been reserved for the aboriginal inhabitants and here whites may only reside in the immediate vicinity of the mines.

The type of asbestos mined throughout this area is crocidolite, better known as Cape Blue Asbestos. The chemical analysis of the fibre is given in Table 1. Crocidolite is the fibrous form of riebeckite and all stages of transformation from a massive riebeckite rock through lamellar riebeckite to asbestiform crocidolite occur in this region. Magnetite is frequently associated with the crocidolite (Vermaas, 1952).

Mining of asbestos first began in the Prieska district in 1893 and gradually spread northwards.
In 1908 production had begun in the Kuruman district. Between 1916 and 1918 a large number of claims were taken up. This northward trend has continued and in about 1950 mining started at Pomfret near the Bechuanaland border (Table 2).

Initially the ore was quarried in numerous small open cast workings. This was followed gradually

TABLE 1

CHEMICAL ANALYSES OF CROCIDOLITE AND AMOSITE (from Vermaas, 1952).

\begin{tabular}{|c|c|c|}
\hline & Crocidolite & Amosite \\
\hline 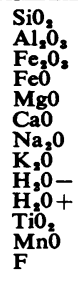 & $\begin{array}{c}51.94 \\
0.20 \\
18.64 \\
19.39 \\
1.37 \\
0.19 \\
6.07 \\
0.04 \\
0.31 \\
2.58 \\
= \\
=\end{array}$ & $\begin{array}{r}49.47 \\
0.63 \\
4.15 \\
35.63 \\
6.57 \\
0.52 \\
0.02 \\
0.020 \\
0.07 \\
2.33 \\
0.25 \\
0.61 \\
0.01\end{array}$ \\
\hline Total & $100 \cdot 73$ & $100 \cdot 46$ \\
\hline
\end{tabular}


TABLE 2

POPULATION OF THE MAGISTERIAL DISTRICTS IN WHICH THE ASBESTOS FIELDS ARE SITUATED (taken from Union Census 1921, and 1951)

\begin{tabular}{|c|c|c|c|c|c|c|}
\hline \multirow{2}{*}{ District } & \multicolumn{3}{|c|}{ Population 1921} & \multicolumn{3}{|c|}{ Population 1951} \\
\hline & Whites & Non-whites & Total & Whites & Non-whites & Total \\
\hline $\begin{array}{l}\text { Prieska } \\
\text { Kuruman } \\
\text { Hay } \\
\text { Postmasburg }\end{array}$ & $\begin{array}{l}3,430 \\
4,713 \\
4,499\end{array}$ & $\begin{array}{c}4,879 \\
16,698 \\
8,814 \\
\text { Included in the } H\end{array}$ & $\begin{array}{r}8,309 \\
21,411 \\
13,313\end{array}$ & $\begin{array}{l}3,361 \\
4,818 \\
2,757 \\
4,887\end{array}$ & $\begin{array}{r}10.847 \\
23,779 \\
9,631 \\
21,019\end{array}$ & $\begin{array}{l}14,208 \\
28,597 \\
12,388 \\
25,906\end{array}$ \\
\hline
\end{tabular}

by a type of shallow mining; inclined shafting became more common after 1930.

According to Frood (1915), the quarrying was a family affair undertaken by the local inhabitants. The men quarried the rock, which was sorted and then hand cobbed by the women and children. Hand cobbing consists of separating the fibre from the banded ironstone by striking the rock cob with a small hammer. As the market was selective, a rotary sieve was sometimes used to grade the fibre and eliminate the small particles of dust. After grading, it was bagged and weighed. The asbestos was then transported by donkey wagon to the nearest rail-head. Before the establishment of the railway in this area between 1923 and 1930, such a journey could last as long as 10 days. This transport was generally undertaken by white youths (farmers' sons) under contract. The white inhabitants played very little part in actual recovery of the fibre, being nearly always employed in the role of managers or overseers, issuing stores and supervising the grading and weighing of the fibres. Farming activities were and are still carried out round the mines.

Since the 1939-1945 war, the demand for crocidolite has enormously increased. The lucrative claims have been bought by registered companies, others have been abandoned. As deeper and richer deposits have been found, vertical shafts are being sunk. However, the mines with large shallow deposits are still using the inclined shaft and tunnel, and quarrying is still used by the few remaining smaller producers. With the building of more mills, hand cobbing has diminished. In 1915 the first crushing mill was established at Koegas in the south. This was followed by a large mill at Kuruman (operated between 1926 and 1931) where it was situated within 300 yards of the main street, close to which cobbing was also done for a few years (1927-1930). This was followed by a mill at Prieska in 1930, which was completely rebuilt in 1957. Griquatown had a small mill in 1928. The practice today is for one mill to serve several mines in the immediate vicinity.

In the early days the manager and labourers lived within a few yards of their place of work, and even today the non-white prefers to live as close as possible, and the children play on the dumps from the mine and mill.

\section{Case Histories}

The following eight case histories illustrate various aspects of the disease and the different types of exposure to asbestos dust.

Case 1.-B.P., a Bantu male, 36 years of age (born 1920), was a mine labourer, and was the first case diagnosed as a mesothelioma with evidence of asbestosis. He was born in the Kuruman district but it is not known whether he worked in the asbestos mines. $\mathrm{He}$ was employed on the Witwatersrand gold-mines underground for two years and in the change rooms for a further 11 years.

A radiograph taken at a mine hospital on August 18, 1955 showed a massive right-sided pleural effusion, and $3,000 \mathrm{ml}$. of fluid was withdrawn. He was admitted to the Witwatersrand Native Labour Association Hospital on August 24, 1955, and two days later aspiration yielded $1,000 \mathrm{ml}$. of thick gelatinous pus "which could be pulled out in threads". He was treated with frequent aspirations and instillation of varidase but without improvement, and he died on February 15, 1956 (Martiny, 1956).

At autopsy the right thoracic cavity was occupied by a large gelatinous tumour which displaced the mediastinum and compressed the left lung. The tumour had infiltrated the pericardium. The right lung was completely compressed by neoplastic tissue (Fig. 2) but the right bronchial tree did not show any evidence of a primary bronchogenic carcinoma. Histological sections of the pleural growth showed a papillary mesothelioma (Fig. 3). There was evidence of asbestosis in both lungs (Fig. 4).

Case 4.-K.H., a white female, 56 years of age (born 1898), was a social worker, who could only have had a short exposure to asbestos as a child and probably a further slight exposure as a young woman. She may have paid several short visits to the mines with her husband at a later period.

She was born in Griquatown where she lived until she was 5 years of age. Her family then moved to Kimberley where from 1916 to 1922 she worked as a clerk in an asbestos warehouse. Her husband owned an asbestos mine from 1933-1940. 


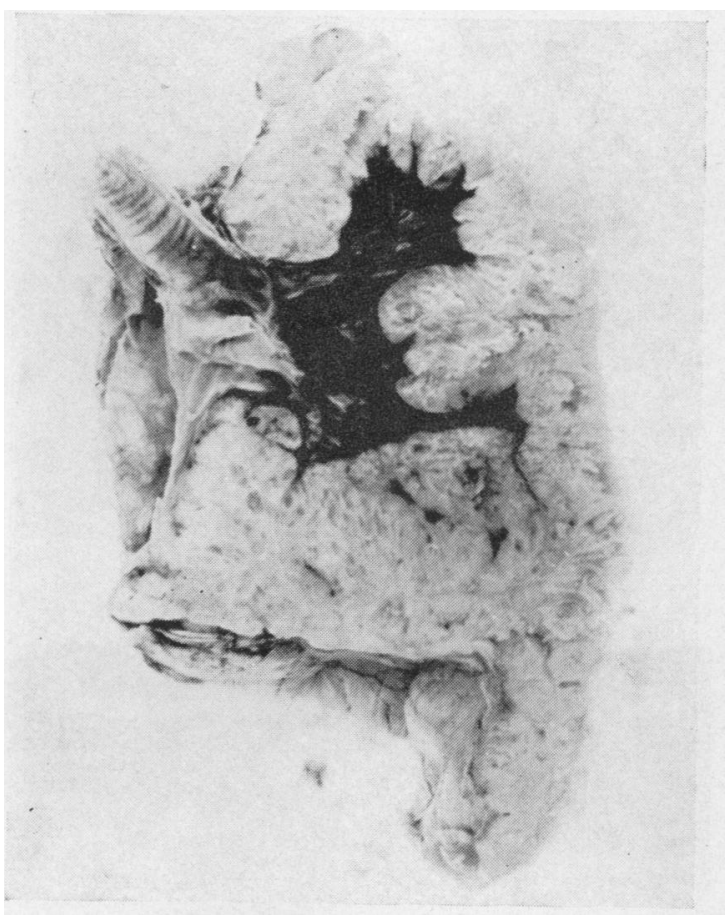

FIG. 2

Fig. 2.-Right lung of Case 1 showing a tumour compressing the lung substance.

Fig. 3.-Cellular structure of tumour of Case $1 . \times 40$ Haematoxylin and eosin.

Fig. 4. Sections of lung from Case 1 showing asbestos bodies. $\times 40$ Haematoxylin and eosin.

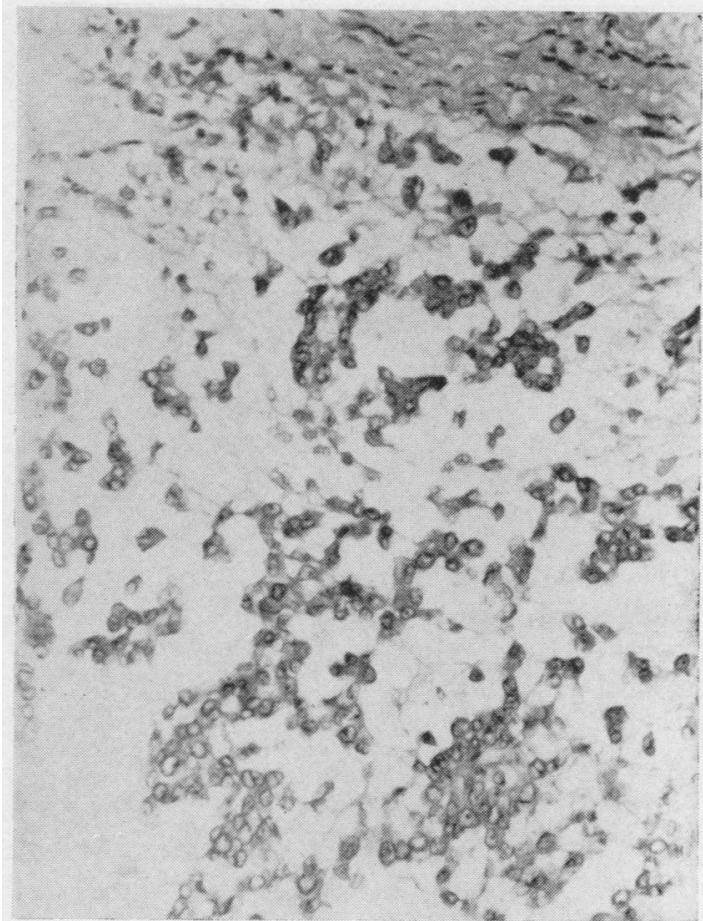

FIG. 3

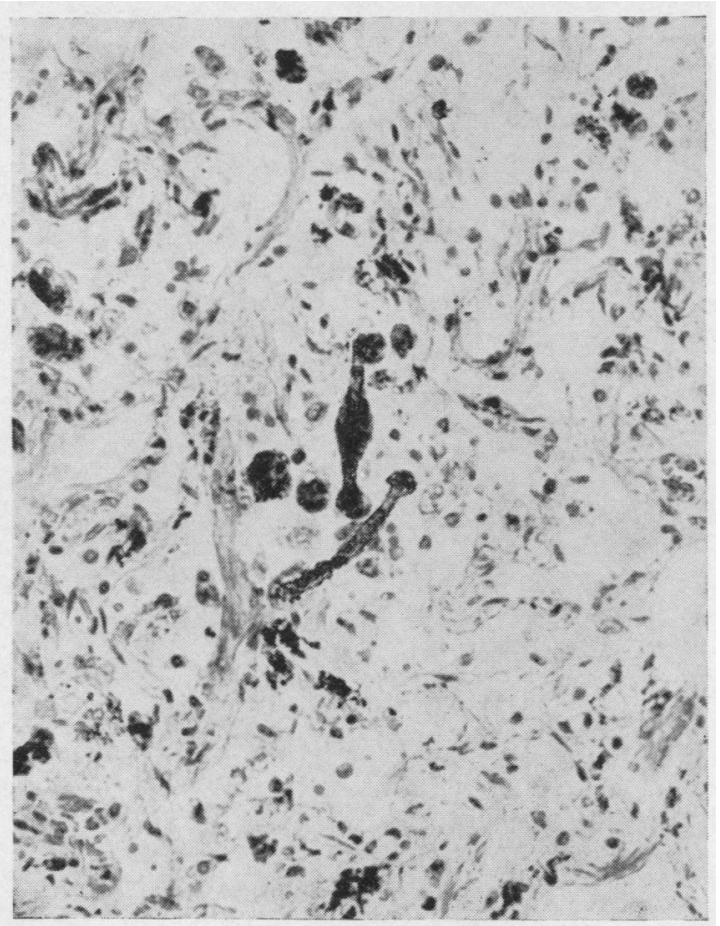

FIG. 4 


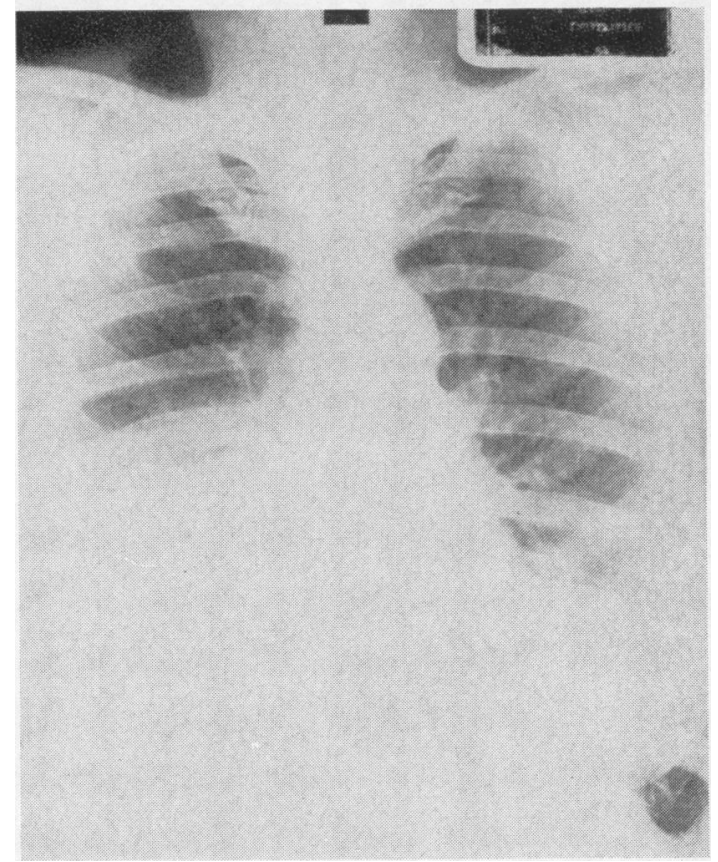

Fig. 5.-On July 21, 1954.

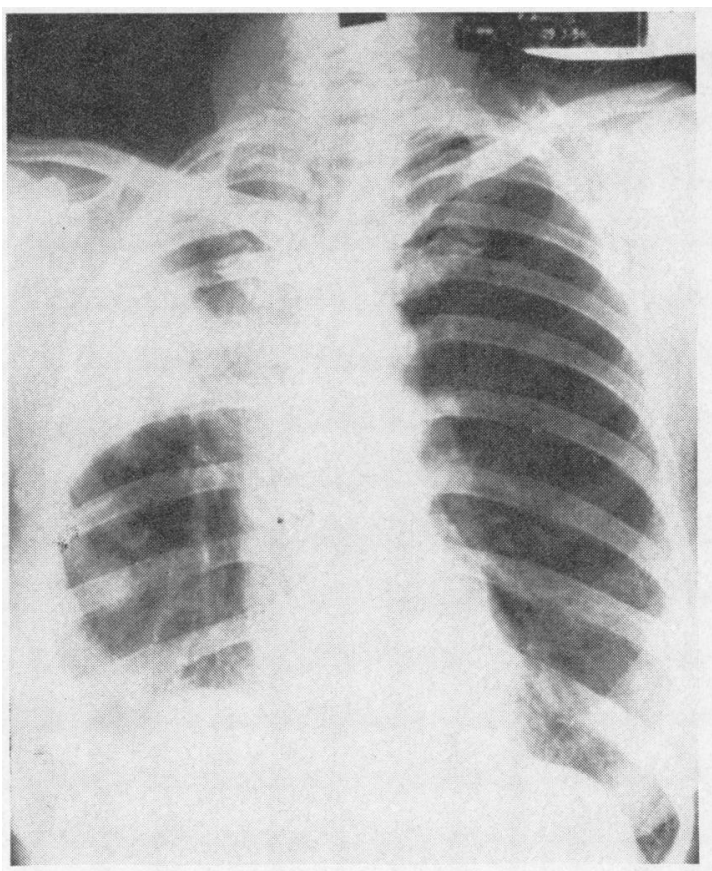

Fig. 7.-On March 3, 1956.

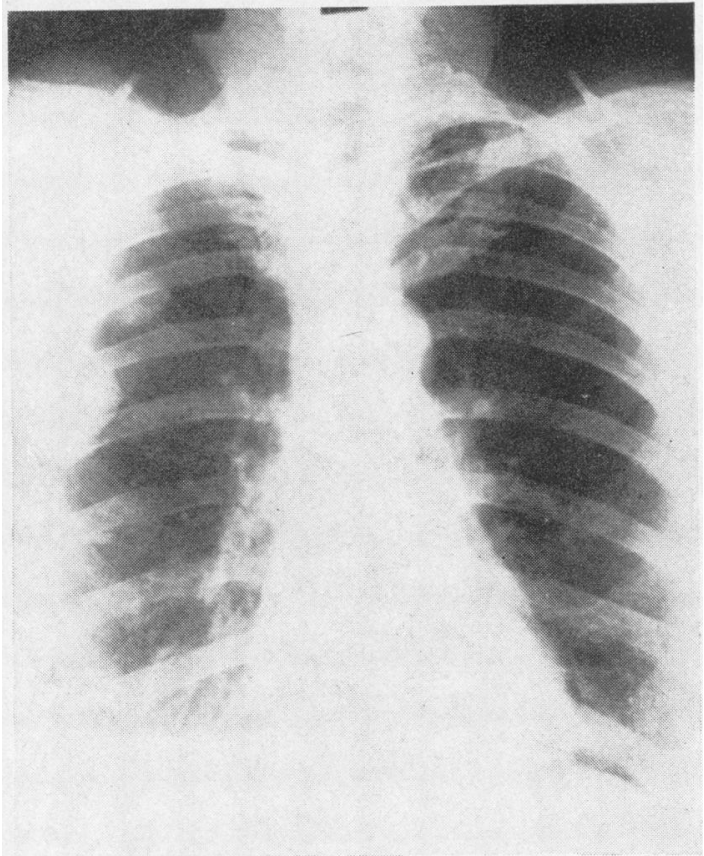

FIG. 6.-On July 7, 1955 .

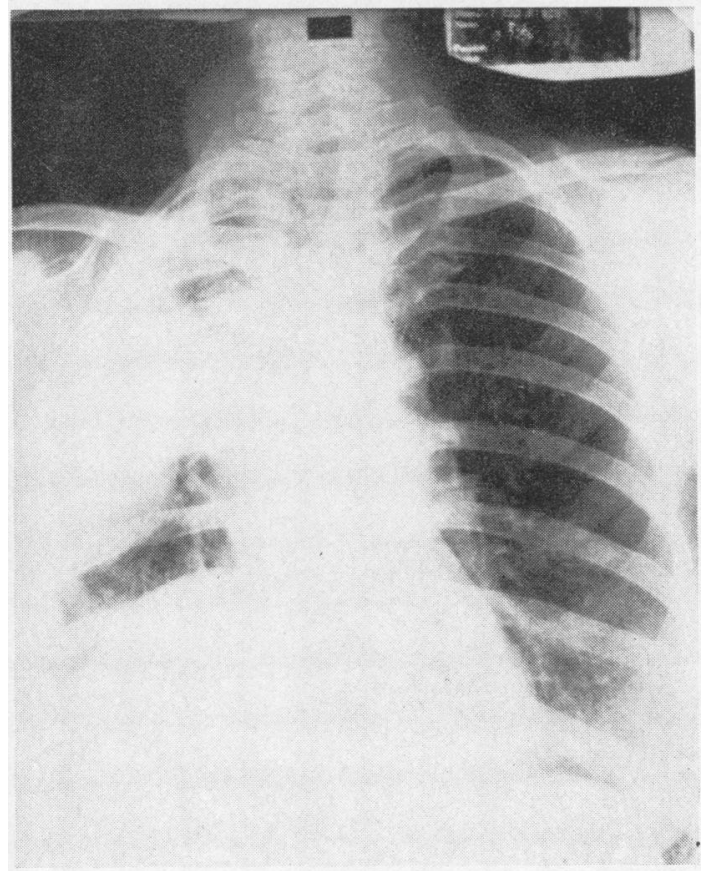

Fig. 8.-On July 3, 1956

Figs. 5, 6, 7, and 8.-Radiographs showing development of tumour in Case 4. 


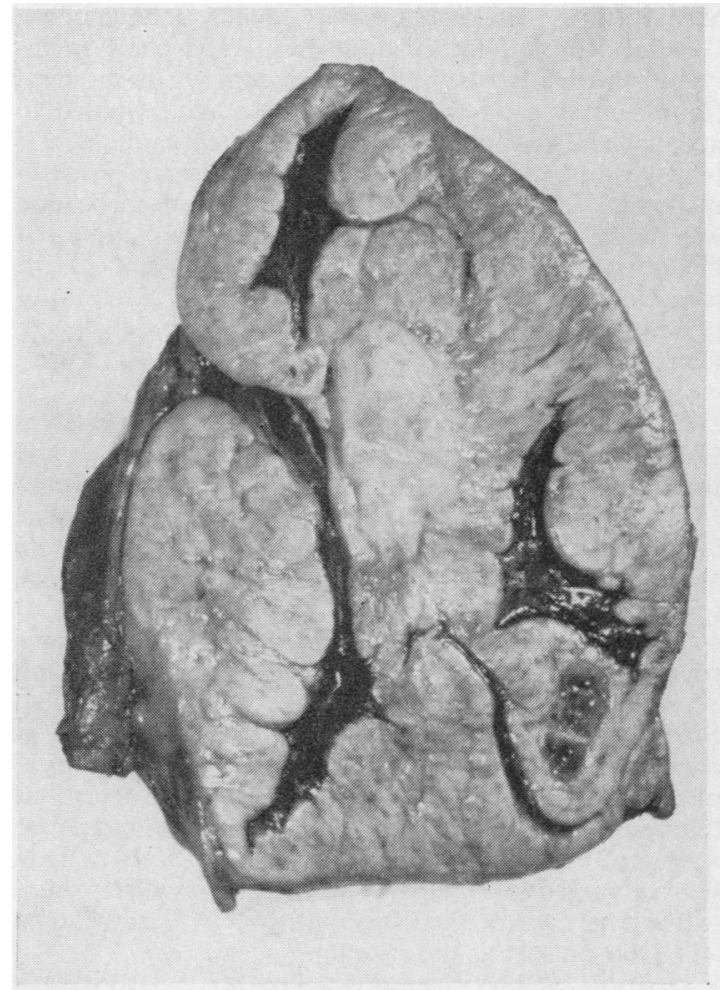

FIG. 9.-Right lung of Case 14.

She was referred to the West End Hospital, Kimberley, on July 19, 1954, because of dyspnoea and right chest discomfort of acute onset. The chest radiograph showed a loculated pleural effusion at the right base. Straw-coloured fluid was aspirated, which on examination was found to be negative for $M$. tuberculosis but contained mesothelial cells arranged in acini. At thoracoscopy in Johannesburg on August 11, 1954 tumour nodules were seen on the parietal pleura. Histological examination of the biopsy specimen showed a mesothelioma. Deep therapy and radio-active gold instillation in September, 1955 caused initial regression of both the pleural fluid and nodules but did not arrest the progress of the disease. She received a further course of $x$-ray therapy without improvement and died in January, 1957. The liver was enlarged and nodular before death but no necropsy was done. (Figs. 5, 6, 7, and 8 show the radiological development of the tumour in this case.)

Case 14.-S.S., a Bantu male, 40 years of age (born 1918), was an asbestos miner. He was born in the Kuruman district and as a child often played on the asbestos dump near an asbestos mine. He subsequently worked with asbestos for several years, being employed at an asbestos mine weighing fibre from 1938-41. In 1942 he worked on a Witwatersrand gold mine but

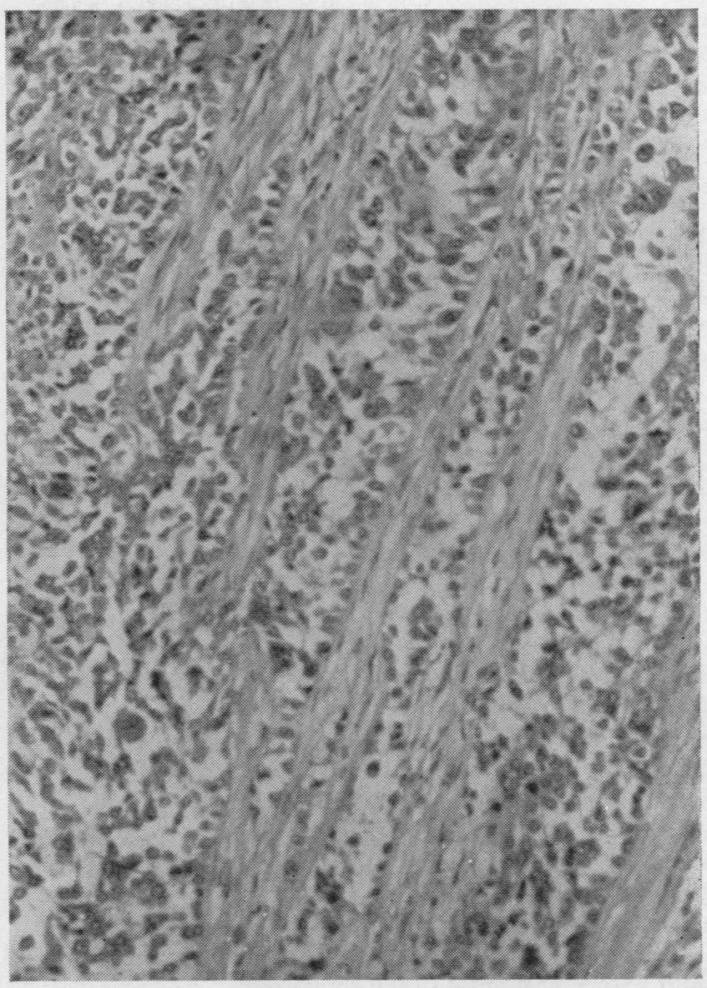

FIG. 10.-Histological sections of tumour from Case $14 . \times 24$ Haematoxylin and eosin.

returned to the Kuruman district in 1943 where he worked as a farm labourer until his final illness.

He was admitted to the West End Hospital on March 3, 1959. He had been well until July, 1958 when he became aware of pains in the right side of his chest. In addition he had a slightly productive cough and shortness of breath on exertion. Chest radiograph on March 9, 1959 showed obliteration of the right lung field. Asbestos bodies were found in the sputum. Needle biopsy showed histological features consistent with a mesothelioma.

Autopsy.-The right chest was occupied by a huge whitish tumour which infiltrated the mediastinum, extending through the diaphragm onto the superior surface of the liver. A straw-coloured effusion was present in the left pleural sac but the left lung was not affected. The mediastinal, cervical, and para-aortic abdominal lymph glands to the level of the renal arteries were infiltrated with tumour.

In the right lung it was found that the tumour mass had infiltrated along the interlobar fissures. The lobes of the lung were compressed into three small segments (Fig. 9). On histological section a papillary type of pleural mesothelioma was seen (Fig. 10) which had infiltrated into the lung parenchyma in some areas. There was marked lymphatic spread throughout the 
lung substance. Numerous asbestos bodies were present in the air spaces and occasional bodies and fibres were seen in the interstitial tissue. The lung itself was markedly atelectatic. Evidence of asbestosis was observed in the left lung.

Case 15. S.S.V., a white female, 42 years of age (born 1916), is a housewife, who lived on a mine near Johannesburg and was treated for tuberculous pleurisy for six months. It was only after the histological diagnosis of a mesothelioma had been made that her previous history was obtained. In addition, it was subsequently learnt that her father (Case 22) had been born on the asbestos field and had a long mining history.

The patient was born in the Griquatown district and went to school at Kuruman. She spent most of her youth in the asbestos belt. She has lived near Johannesburg for 20 years.

In March, 1958 this patient developed right chest pain and rapidly increasing shortness of breath. She was admitted to hospital and $2,500 \mathrm{ml}$. of slightly bloodstained fluid was removed from the right chest. A thoracoscopic examination was carried out on July 27, when a small biopsy was taken but this consisted of fibrous tissue. Bronchoscopy was normal and no neoplastic cells were observed in the bronchial washings. $M$. tuberculosis was not cultured from numerous specimens of sputa, pleural fluid nor from the bronchial washings. She was admitted to a Johannesburg nursing home on October 16, 1958.

Radiographs then showed massive thickening of the right pleura with fluid in the right chest. At thoracotomy (Mr. Dennis Fuller) the parietal pleura was $2 \mathrm{~cm}$. thick, "hard as rock" and stripped with great difficulty from the chest wall. The visceral peel stripped fairly easily from the upper lobe but separation became more difficult over the lower lobe where the peel was thicker. During the decortication a necrotic mass was found in the parenchyma of the left lower lobe. At the base, confluent with the diaphragm and perhaps the mediastinum, was a hard craggy mass which could not be removed. Histological sections of the specimen revealed an adenoid form of tubular mesothelioma. Subsequently three specimens of sputum were examined for asbestos bodies but none were found.

The patient is still alive (April, 1960), but her condition is deteriorating.

Case 22.-D.A.B., a white male, 68 years of age, and a farmer, was the father of the previous patient. Although a diagnosis of pleural mesothelioma was made in January, 1957 it was not until July, 1959 that details of his exposure to asbestos was obtained.

He was born in Griquatown and went to school there. He worked in Kuruman, Postmasburg and Griquatown until the age of 62 . Between 1918 and 1932 he worked as an asbestos miner underground and was mostly in charge of blasting. Between 1932 and 1944 he farmed in the district but returned to asbestos mining from 1945 to 1952 .

In January, 1957 the patient consulted his doctor because of left-sided chest pain with cough and slight haemoptysis. He was referred to the Johannesburg General Hospital for investigation. The chest radiograph showed gross pleural thickening with a basal pleural effusion on the left side. He was admitted to hospital and on June 10, 1957 a thoracoscopic pleural biopsy was taken. This showed the features of a mesothelioma. On June 24, 1957 an attempt at decortication was made. The left upper lobe was stripped easily but the grossly thickened pleura was so adherent to the lower lobe that the attempt was abandoned. Sections of the pleura confirmed the diagnosis of mesothelioma. He died on December 13, 1957.

Case 16.-A.N.V., a white male, 50 years of age (born 1906), was a farmer, who was born at Griquatown and went to a village school near an asbestos mine. From 1914-16 he transported asbestos in donkey waggons from Hay to Prieska. During these journeys he often slept on asbestos bags. In 1914 he worked in an asbestos mine for a month.

The patient became ill in December, 1955 with vague substernal pain and dyspnoea. A left-sided pleural effusion was diagnosed and he was referred to Mr. J. K. Bremmer in Pretoria. There was no evidence of malignancy in bronchial and scalene biopsies. Some apical pleural thickening and a dense homogeneous opacity at the base of the left lung was seen in the radiograph on August 3, 1956. Thoracotomy (Mr. Bremmer) in February, 1957 revealed a thickened nodular pleura with a large mass on the left diaphragm. A mesothelioma was seen on histological section.

In April, 1959 he was examined by Mr. J. D. Visser in Kimberley who found small nodules in the subcutaneous tissue over the neck and chest. A large firm mass was found in the thoracotomy wound and a mass was present in the left hypochondrium. There was generalized lymphadenopathy and numerous nodules were present on the tongue. Chest radiographs showed the left pleural cavity to be obliterated. He was one of the few cases to develop widespread metastases.

A biopsy of one of the subcutaneous chest nodules showed a similar appearance to those seen in the original specimen from the pleura. The patient died on May 22, 1959. No necropsy was performed.

Case 24.-D.G., a white male, 32 years of age (born 1922), by profession an accountant, was born in England but came to South Africa as an infant. He spent his early childhood in Kuruman and left at the age of 7 . He later qualified as a chartered accountant in Kimberley. In 1944, at the age of 22 , he had been discharged medically unfit from the army because of a left pleural effusion. Neither then nor on many subsequent occasions were acid-fast bacilli found, either in sputum or pleural fluid. His only subsequent contact with asbestos was the auditing of the books of an amosite mine in the Transvaal.

In September, 1953 he complained of left-sided chest pains and shortness of breath. A radiograph of the chest showed flattening of the diaphragm on the left side with obliteration of the costophrenic angle and thickening of the oblique fissure. He was seen on numerous occasions 


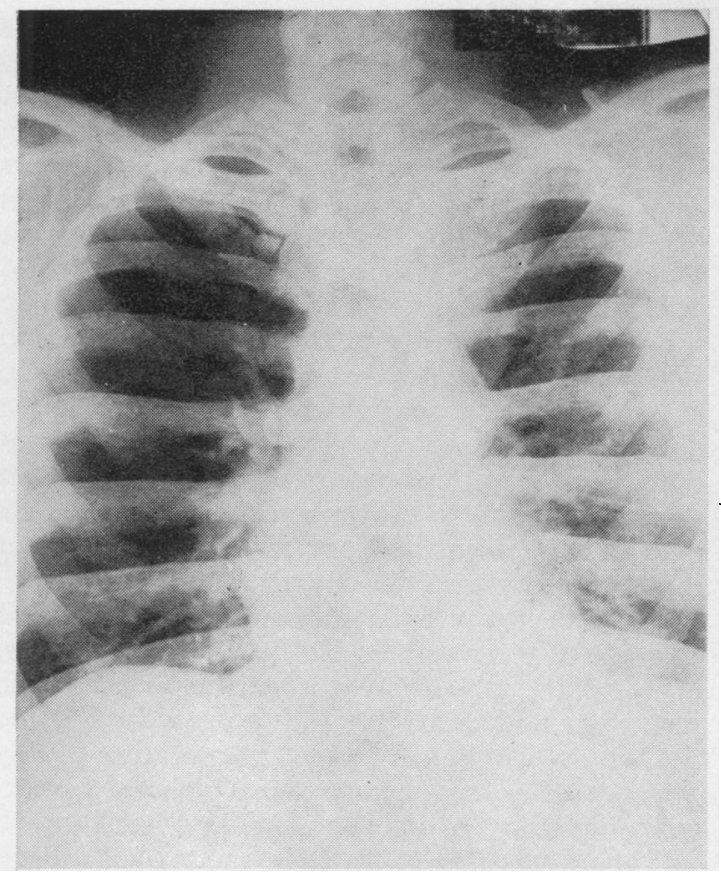

Fig. 11.-On September 11, 1956.

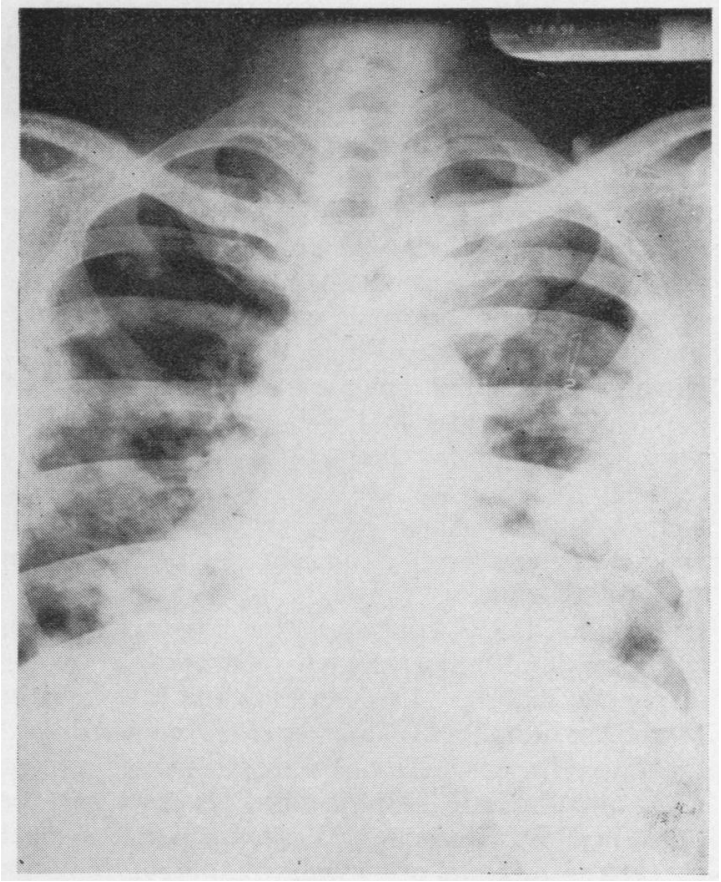

Fig. 12.-On August 23, 1957.

Figs. 11 and 12.-Radiographs showing development of tumour in Case 24.

from 1953 to 1957. A radiograph taken early in 1956 showed the development of a left superior mediastinal shadow which enlarged progressively (Fig. 11) and later the de relopment of diffuse nodular pleural thickening on the left. During 1957 similar but less marked changes developed on the right side (Fig. 12). He consented to biopsy in June, 1957, and, at operation, a diffuse pleural malignancy was present.

Sections of the parietal pleura only were removed and the histological appearances were those of a mesothelioma. He died on October 6, 1957. A necropsy was not performed.

Case 30.-G.F., a white male, 50 years of age (born 1909), is a storekeeper, with a history of industrial exposure. He has never been near the Cape Asbestos Fields.

He was born in South West Africa and lived there until the age of 21. From the age of 21 to 26 he worked in a factory in the Cape as a boiler-maker and fitter. He volunteered the information that he had worked continuously with asbestos, lagging pipes and boilers. He remarked that the removal of asbestos lagging from old pipes created a very dusty atmosphere and that he would cough a lot at such work. Between 26 and 32 years of age he worked in a factory in Johannesburg in a similar capacity but was not exposed to such heavy dust concentrations. For the past 20 years he had not been in contact with asbestos. Enquiries were made from the factory in the Cape as to the nature of the asbestos used and these have revealed that during the relevant periods Cape crocidolite was exclusively in use.

He was first seen on March 14, 1959 complaining of cough, pain in the right chest and recent onset of breathlessness. Three pints of fluid had been aspirated from the pleura and cytological examination showed the presence of malignant cells. The radiograph showed marked pleural thickening and hydro-pneumothorax. On March 17, 1959, a thoracoscopy was done. The pleura felt thickened and the lung was collapsed and immobile. Several biopsies were taken. These showed the presence of a mesothelioma. The underlying lung showed the presence of asbestosis. He was treated with nitrogen mustard intra-pleurally and his condition temporarily improved. When last examined he complained of increased breathlessness.

\section{Discussion}

In 1924 Robertson denied the existence of primary malignant tumours of the pleura and considered them to be secondary in origin. Since then, on the one hand, Willis $(1948,1953)$ and Smart and Hinson (1957) have supported Robertson's views, while on the other hand, primary neoplasms of this nature have been described by many authors in recent years. These include Tobiassen (1955) in Sweden, Belloni and Bovo (1957) in Italy, Godwin (1957) in the United States, and McCaughey (1958) 
in Britain. Evidence in support of the mesothelial origin of these tumours can be found in the tissue culture experiments of Stout and Murray (1942) and Sano, Weiss, and Gault (1950).

The variegated histological pattern of tumours arising from the mesothelium of the pleura was remarked on by Klemperer and Rabin (1931). Such a variation is appreciated when the multipotentiality of the cells lining coelomic cavities are considered. Maximow first demonstrated this feature in 1927. Novak (1931) stated that the mucosa of all parts of the Müllerian canal and the germinal epithelium were derived from these cells. Keasbey (1947) showed that in the embryo, the mesonephros, metanephros, Wolffian body, genital ridge, and all dependent urogenital structures are derived from the mesothelium.

Campbell (1950) considered the presence of both epithelial and mesenchymal elements a major diagnostic feature. In describing the histology of 11 of these tumours McCaughey (1958) demonstrated that either the epithelial or the mesenchymal element might predominate. He classified his cases into the following four groups: Tumours of epithelial character; tumours of mesenchymal type; tumours of mixed type; and tumours of anaplastic type.

Using McCaughey's classification on our series of tumours, the majority are, as in Campbell's series, of the mixed type. Of the remainder, a few showed the papillary tubular structure of the "tumours of epithelial character", and there were several of the anaplastic type. One case had the appearances of a "tumour of mesenchymal type" but even in this case primitive tubular structures were seen.

Apart from the original case all the histological diagnoses were made on biopsy material. Three of these biopsy findings were confirmed at necropsy. In the remainder, we have had to rely on clinical and radiological examination to exclude other primary sites of malignancy.

Following the work of Meyer and Chaffee (1939, 1940 ), the possibility of demonstrating hyaluronic acid in these tumours both chemically and histochemically has been considered as a diagnostic aid. Both these investigations are still in an early stage (Harington, 1959).

Preliminary results of the histochemical experiments show that there is metachromatic substance in both the stroma and glandular structures of the tumours. This metachromasia can be reversed by incubation with testicular hyaluronidase. This material stains strongly with Hale's (1946) colloidal iron method. The periodic acid Schiff technique has given variable reactions. These results are not specific for hyaluronic acid but are strongly suggestive of its presence.
The amount of metachromatic substance in these tumours has varied considerably. This we think is partly due to the fact that until recently we had not appreciated the solubility of hyaluronic acid in aqueous media and the majority of these tumours were fixed in $10 \%$ formol-saline. Further, Lison (1953) states that the metachromasia of hyaluronic acid is optimal at a concentration of $1 / 10,000$ and gradually decreases at higher levels. When the high concentrations that Meyer and Chaffee $(1939,1940)$ found in their tumours are considered, this variation in metachromatic properties seems to have been partially explained. In addition, with the great differences in the histology of the various lesions, it would be logical to expect certain tumours with a marked adenoid appearance to secrete more than those with an essentially non-glandular structure.

Three of the five autopsies performed showed evidence of peritoneal metastases. In the other two, intra-thoracic spread was observed, in one case to the other lung and chest wall, and in the second to the mediastinal lymph glands and pericardium. Biopsy evidence of metastases has been obtained in two cases, one from the omentum and the other from the subcutaneous tissue of the chest wall; while a third patient developed an implantation nodule in the thoracotomy scar which showed a similar appearance to that of the previous biopsy specimen.

The first recorded case of carcinoma of the lung associated with asbestos was described by Lynch and Smith (1935). By 1955, according to Doll, a total of 61 cases had been reported. Included in these cases was one mesothelioma. Cartier (1952) mentioned two cases of diffuse mesothelioma from a Canadian chrysotile mine. A further three cases were described by van der Schoot (1958). Unfortunately no indication is given in the literature regarding the type of asbestos to which the majority of recorded cases of carcinoma were exposed. However, discussion with management and medical officers of two of the factories, in which the majority of the cases reported in Britain were employed, suggests that most of these workers were handling chrysotile asbestos (Wagner, 1958). The possibility that some of these people may also have been exposed to crocidolite dust cannot be excluded.

Attempts to produce tumours in experimental animals by exposing them to asbestos dust have been made. Vorwald and Karr (1938) were unsuccessful. Lynch, McIver, and Cain (1957) succeeded in producing tumours in mice, but lung neoplasms in his control animals were far too numerous for the results to be considered significant. On the other hand Schmähl (1958) working in Druckrey's laboratory has been able to produce sarcomas in rats. This has occurred after subcutaneous and 
intraperitoneal inoculation of both asbestos fibres and dust. He states that "mineral asbestos" was used but does not name the variety.

In our series of mesotheliomata, histological evidence of asbestosis has been observed in eight of the 10 cases in which lung parenchyma was included in the specimen examined. No lung tissue was present in the biopsies from the remaining 23 cases. It was only in the four cases that came to necropsy that large sections of the lung tissue were available for examination. In all of these specimens evidence of asbestosis was found.

At first it was thought that the presence of numerous asbestos bodies, fragments of fibre, and dust immediately below the pleural elastic laminae in these specimens, might have been significant in the pathogenesis of the tumours. However, it is more probable that this distribution is a result of the marked atelectasis. Similar features have been observed in atelectatic lungs of asbestos miners in which no mesotheliomas have been observed.

Pleural fibrosis has been a common finding in cases of asbestosis and in some cases large pleural plaques measuring up to $1.0 \mathrm{~cm}$. in thickness have been seen. These plaques, which were first described by Gloyne (1933), have been observed following exposure to both amosite and crocidolite asbestos dusts. In these cases of benign pleural thickening no evidence of stromal metachromasia has been observed.

In all the histological sections of pleura examined in the cases of these mesotheliomas and in more than 100 cases of asbestosis, no asbestos bodies, fragments of fibres, or dust have been observed beyond the pleural elastic laminae.

Three patients from the Kuruman district, with clinical and radiological features consistent with those of diffuse pleural mesothelioma had markedly abnormal cells in the pleural fluid. These cells showed no specific features to distinguish them from cells originating in secondary malignant pleural deposits nor from the grossly atypical cells sometimes seen in non-malignant pleural effusions. As no biopsy or autopsy examinations were obtained in these cases they have been excluded from the series.

The pathological evidence for associating these tumours with asbestos exposure is not conclusive. As previously stated, only in eight of the 33 cases has evidence of asbestos been demonstrated. Of these, six had a definite mining history and one had been exposed to asbestos while lagging steam pipes. The other case was born in the Kuruman district and nothing else is known of him, until his arrival at a Witwatersrand gold-mine at the age of 23 . In the remaining 25 cases we can only present circumstantial evidence of exposure to asbestos dust
(Table 3). Eighteen of these 25 cases were born in the vicinity of the mines and two arrived in the district as infants. Of these 18 people 11 admit definite childhood exposure to the dust and two others were exposed industrially in later life. In addition two patients with childhood exposure later worked in the asbestos mines. Three cases arrived in the region at an older age but were employed either on the mines or in transporting asbestos. A further three of these 25 cases have had industrial exposure, and in only one case do the relatives deny any exposure to asbestos dust.

The four industrial cases are significant. Two of the patients were lagging locomotive boilers and one was lagging steam pipes. A man, who was an upholsterer by trade, was employed in making fire-proof clothing from 1939-1945. As far as can be ascertained these people were never in the Griqualand district. These findings tend to add support to asbestos being the common factor in the development of these tumours, and to counter the suggestion that there may be some other environmental cause in the region of Griqualand West.

If asbestos dust is a factor in the occurrence of these tumours, similar cases might have been expected from the neighbourhood of the Transvaal asbestos mines in the Pietersburg and Lydenburg districts, where crocidolite and amosite asbestos is mined. According to Vermaas (1952), crocidolite and amosite occur in the same seams in the Pietersburg district. As can be seen from Table 1, amosite is similar in composition to crocidolite. In the past four years the lungs of 24 cases of asbestosis from the Lydenburg district have been examined. In this material two cases of adeno-carcinoma have been observed. The one was in a white miner with 19 years' service, who had an adeno-carcinoma arising from a bronchus. The other case was a Bantu miner who had a peripheral tumour. No service record was obtainable in this case. Only one case of asbestosis has been received from the Pietersburg area. All of these men were actually employed on the mines at the time of death, the majority having had a relatively short service. Our findings suggest that mesothelioma occurs 20 to 40 years or more after exposure to dust. Until comparatively recently the mining in the Transvaal has been on a small scale, and there were no settlements in the vicinity of the mines.

The lungs of 20 asbestos miners from the Cape Asbestos Field have been examined, in whom no mesothelioma was observed. One autopsy specimen consisting of three fragments of lung showed asbestosis and an adeno-carcinoma. Radiological features of asbestosis have been observed in many miners from this region, without any suggestion of 
TABLE 3

DIfFUSE PLEURAL MESOTHELIOMA: ASSOCIATION WITH ASBESTOS

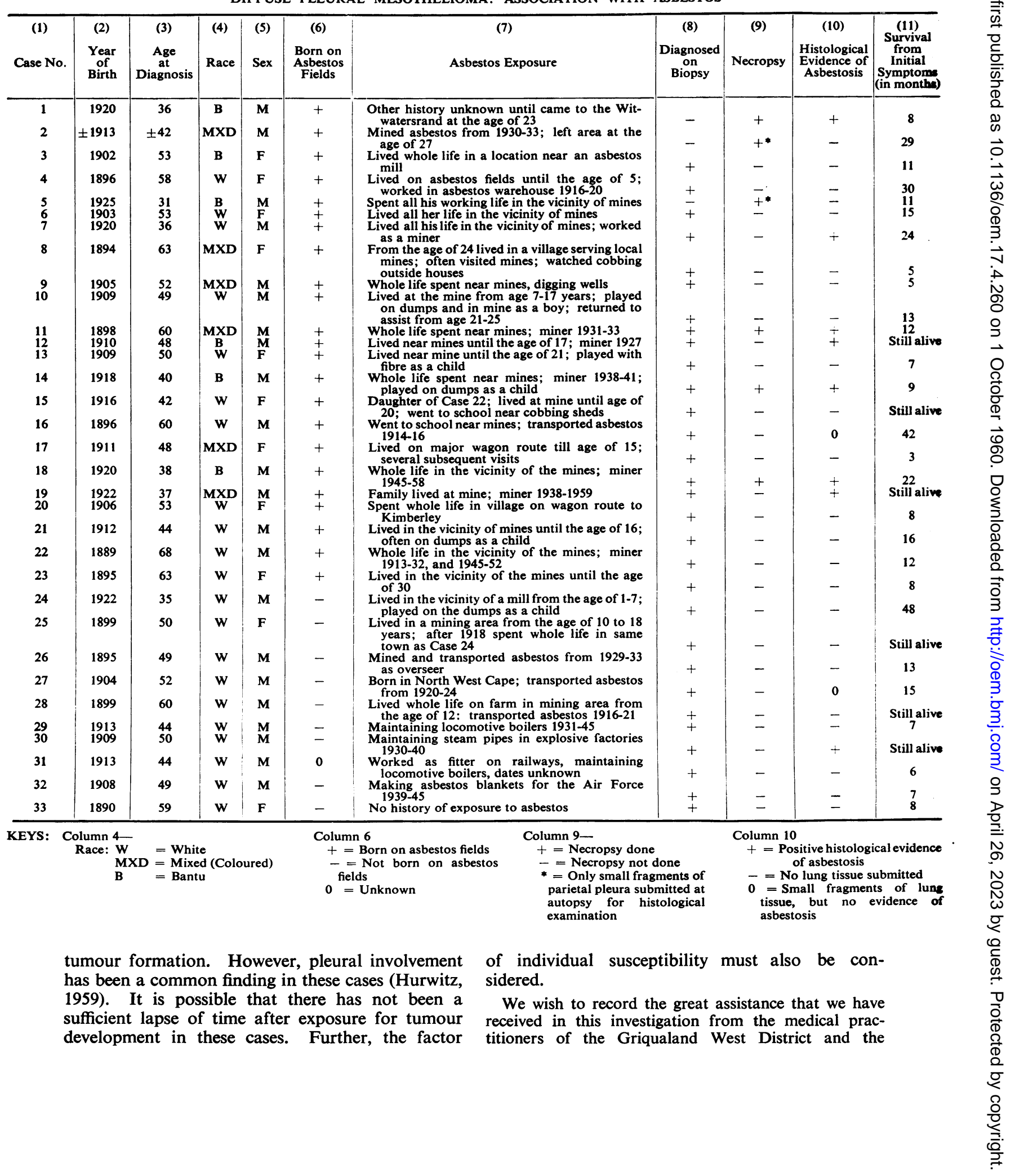


thoracic surgeons and pathologists in Johannesburg, Pretoria, and Durban.

We thank the Secretary of Health for permission to publish this paper.

\section{REFERENCES}

Belloni, G., and Bovo, G. (1957). Acta med. patav., 17, 367.

Campbell, W. N. (1950). Amer. J. Path., 26, 473.

Cartier, P. (1952). Arch. industr. Hyg., 5, 262. (Contribution to the discussion.)

Doll, R. (1955). Brit. J. industr. Med., 12, 81.

Frood, G. E. B. (1915). Memorandum on the Asbestos Industry in the Cape Province. Report of the Government Mining Engineer, Union of South Africa, pp. 76-82

Gloyne, S. R. (1933). Tubercle (Lond.), 14, 493.

Godwin, M. C. (1957). Cancer (Philad.), 10, 298

Hale, C. W. (1946). Nature (Lond.), 157, 802

Hall, A. L. (1930). Asbestos in the Union of South Africa. Memorandum no. 12. Geological Survey of South Africa.

Harington, J. S. (1959). Personal communication.

Higginson, J., and Oettle, A. G. (1957). Acta Un. int. Cancr., 13, 949. Hurwitz, M. (1959). Proceedings of International Conference of Experts on Pneumoconiosis. Johannesburg, Feb. 1959. Churchill, London. (In the press.)

Keasbey, L. E. (1947). Amer. J. Path., 23, 871.

Klemperer, P., and Rabin, C. B. (1931). Arch. Path. (Chicago), 11, 385.

Lison, L. (1953). Histochimie et Cytochimie Animales, pp. 332-337. Gauthier-Villars, Paris.

Lynch, K. M., and Smith, W. A. (1935). Amer. J. Cancer, 24, 56.

-, McIver, F. A., and Cain, J. R. (1957). A.M.A. Arch. industr. Hlth, 15, 207.
Martiny, O. (1956). Proc. Transv. Mine med. Offr' Ass., 35, 63. Maximow, A. (1927). Arch. exp. Zellforsch., 4, 1.

Meyer, K., and Chaffee, E. (1939). Proc. Soc. exp. Biol. (N.Y.), Meyer, K, 797 ,

,- 42, (1940). J. biol. Chem., 133, 83.

Novak, E. (1931). Amer. J. Obstet. Gynec., 22, 826.

Robertson, H. E. (1924). J. Cancer Res., 8, 317.

Sano, M. E., Weiss, E., and Gault, E. S. (1950). J. thorac. Surg., Schmähl,' D. (1958). Z. Krebsforsch., 62, 561.

Smart, J., and Hinson, K. F. W. (1957). Brit. J. Tuberc., 51, 319

Stout, A. P, and Murray, M. R. (1942). Arch. Path. (Chicago) 34, 951 .

Tobiassen, G. (1955). Acta path. microbiol. scand., Suppl. 105, p. 198.

van der Schoot, H. C. M. (1958). Ned. T. Geneesk, 102, 1124.

Vermaas, F. H. S. (1952). Trans. geol. Soc. S. Afr., 55, 199.

Vorwald, A. J., and Karr, J. W. (1938). Amer. J. Path., 14, 49

Wagner, J. C.' (1958). Memorandum on Pneumoconiosis Research in Europe. Submitted to the C.S.I.R.

Willis, R. A. (1948, 1st ed. and 1953). Pathology of Tumours. Butterworth, London.

\section{Addendum}

By the end of June 1960, a total of 47 cases of mesothelioma had been identified. In 45 of these a possible association with exposure to crocidolite has been established. In one case a mesothelioma of the peritoneum was present.

\section{THE JULY (1960) ISSUE}

The July (1960) issue contains the following papers:-

Decompression Sickness during Construction of the Dartford Tunnel. By F. Campbell Golding, P. Griffiths, H. V. Hempleman, W. D. M. Paton, and D. N. Walder.

A Comparison of the "High-altitude" and "High-pressure " Syndromes of Decompression Sickness. By M. de G. Gribble.

Phosgene Poisoning Caused by the Use of Chemical Paint Removers Containing Methylene Chloride in Ill-ventilated Rooms Heated by Kerosene Stoves. By W. B. Gerritsen and C. H. Buschmann.

A Study on the Acute Toxicity of the Tri-aryl Phosphates Used as Plasticizers. By H. F. Bondy, E. J. Field, A. N. Worden, and J. P. W. Hughes.

Aerosol Inhalation of $\mathrm{CaNa}_{2}$ E.D.T.A. (Mosatil) by Workers Constantly Exposed to Lead Poisoning. By LJ. Petrović, M. Stanković, M. Savićević, and D. Poleti.

A Biochemical Study of the Urinary Protein of Men Exposed to Metallic Mercury. By J. C. Smith and Agnes R. Wells.

A Simplified Method for the Estimation of Nickel in Urine. By J. Gwynne Morgan.

Clinical, Bronchographic, Radiological, and Physiological Observations in Ten Cases of Asbestosis. By G. L. Leathart.

The Measurement of Occupational Mortality. F. D. K. Liddell.

Observations on the Occupational Life History of the Coal Face Worker at Two Collieries. By O. P. Edmonds and D. S. Kerr.

The Assessment of Electroencephalographic Changes and Memory Disturbances in Acute Intoxications with Industrial Poisons. By B. Chalupa, J. Synková, and M. Ševčík.

Book Reviews.

A number of copies are still available and may be obtained from the Publishing Manager, British Medical Association, Tavistock Square, W.C.1, price 17s. $6 d$. 